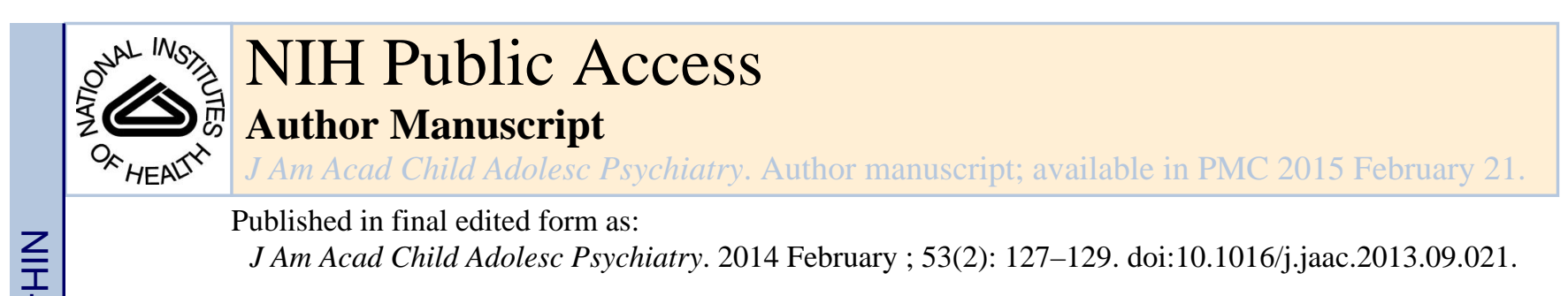

\title{
Policing the Teen Brain
}

Jeff Q. Bostic, MD, EdD, Lisa Thurau, JD, Mona Potter, MD, and Stacy S. Drury, MD, PhD Drs. Bostic and Potter are with Harvard Medical School and Massachusetts General Hospital. Dr. Potter is also with McLean Hospital. Ms. Thurau is with Strategies for Youth. Dr. Drury is with Tulane Medical School.

More than 100 years after the creation of the juvenile court, state juvenile justice policies still promote adult approaches, despite consistent neurobiological evidence that the adolescent brain processes, perceives, and responds differently than adult brains. Although frequently the first responders in youth cases, police officers rarely receive adequate training in effective communication and interaction strategies with youth. Strategies for Youth found that most police academies contacted devote less than $1 \%$ of training to interactions with adolescents, ${ }^{1}$ yet $20 \%$ to $40 \%$ of juvenile arrests are for "contempt of cop" offenses, such as questioning or "disrespecting" an officer. ${ }^{2}$ Incarceration of adolescents fails to decrease recidivism and compounds the negative impacts on the $60 \%$ to $70 \%{ }^{3}$ of youth in correctional facilities who have significant untreated mental health problems. ${ }^{4} \mathrm{We}$ found that police officer training in neuro-developmentally sensitive techniques markedly decreased teen arrests and improved police-teen interactions in diverse American communities.

In 1998, the Boston public schools directed students to take public transportation to school, and within 1 year, 40,000 students used public transit daily. The Massachusetts Bay Transit Authority police implemented "zero tolerance" policies that led to 646 juvenile arrests that year. In response to the large number of youth arrested for minor offenses (disorderly conduct, trespass), an attorney (L.T.) and a child psychiatrist (J.Q.B.) devised training to address officers' perceptions that juvenile misbehavior would best respond to arrest and incarceration. The 2-day training included information about the functioning of the adolescent brain to help officers understand and respond more effectively to low-level offenses.

After the training, juvenile arrests decreased from 646 in 1999 to 74 in 2009. Arrests have remained consistently below 100 each year since, with no decrease in public safety.

Subsequent training occurred at other Massachusetts police departments, to other sites across the United States, and to school resource officers in 4 states (listed in Table 1). The Massachusetts Municipal Police Training Academy plans to require all recruits to have this training by 2014 .

(C) 2014 American Academy of Child and Adolescent Psychiatry

Correspondence to Jeff Q. Bostic, MD, EdD, Assistant Clinical Professor, Massachusetts General Hospital/Harvard University, Child Psychiatry, 2 Faith Road, Windham, NH 03087; jbostic@ partners.org.

Dr. Potter reports no biomedical financial interests or potential conflicts of interest. 
The training includes the following components.

1. Neuroscience: Adolescents process information through the amygdala more than the prefrontal cortex, and this is accentuated during emotionally charged interactions, yielding more erratic responses. The training emphasizes how a conversation involving officers speaking from the "frontal lobe" to adolescents answering from the "amygdala" may require translation and patience for each participant to understand the other. The explanation of "brain road construction" (the pruning of neurons during adolescence) helps officers understand why adolescents require more time to process information, often need instructions repeated calmly and succinctly, and benefit from explanations or alternatives and consequences (e.g., "if you do this, then this likely will happen; however, if you do that, then that might happen"). This teaches officers to identify and suggest preferred behaviors rather than telling adolescents what not to do. Officers are encouraged to approach the adolescent in an emotionally neutral manner and to focus on their own behaviors, language, and timing and those of youth.

2. Developmental Differences: The adolescent's task of separating from parents and finding his/her place among peers may increase conflict with adults as adolescents seek to "prove" their autonomy. Adolescents often "posture" among their peers to appear more powerful or desirable; they argue and "go down in a blaze of glory" (e.g., get arrested) rather than accede to simple police requests. Challenging authority is an especially powerful temptation when a crowd of peers is watching, even when the behavior obviously harms short- and long-term prospects. Similarly, clarity about the moral imperatives of adolescents ("worse to snitch than to break the law") allows officers to recognize why adolescents may group together to protect or defend peers. Officers are encouraged to help youth "save face," decrease group escalation, and pose options that complement adolescent motives for autonomy and status among peers.

3. Mental Health Differences in Adolescents: Officers watch short training videos depicting an officer's encounter with adolescents showing symptoms of depression, anxiety, developmental disorder, psychosis, and oppositional-defiance disorder. The first video portrays a negative encounter in which the officer escalates the situation; the second shows the officer using preferred (and more successful) tactics, such as speaking slowly, giving the youth space, and repeating requests. The videos help officers see the application of appropriate techniques, particularly with adolescents who pose additional challenges because of mental health conditions.

4. Trauma: Trauma exposure is highly prevalent among youth encountered by officers. ${ }^{5}$ Understanding the impact of trauma on executive function, attention, emotional processing, and arousal prepares officers to anticipate and recognize traumatized behavioral responses of adolescents. Youth exposed to repeated community and interpersonal violence may process anger and threat cues more rapidly and have increased difficulty disengaging from those cues; the training 
teaches officers to recognize these responses and a calmer, emotionally neutral approach that offers youth more time to self-regulate.

5. Demographic and Cultural Factors Influencing Youth Behavior: Particular demographic factors-lower socioeconomic status, victimization, exposure to violence, and truancy - may have an acute impact on police interactions with youth. This aspect of the curriculum takes into account factors unique to each city or region, emphasizing sensitivity to generational and cultural differences regarding police authority.

6. Juvenile Law for Law Enforcement: This part of the training demonstrates recent research on peer pressure and false confessions and shows why using adult approaches with youth often fails or leads to false confessions and exclusion of evidence at trial. It teaches officers more appropriate approaches, including a Miranda warning geared to youth.

7. Role Plays with Adolescents: The training concludes with the role playing of different approaches by local adolescents and police officers. Youth are asked to explain how they feel with each approach and why they are more or less likely to comply with an officer's directives. These interactions illuminate for officers how adolescents perceive them, how the adolescents process information, and how developmental stage and cultural sensitivity influence interactions.

Police play a large role in the lives of many adolescents. Young people are often fearful and defensive when confronted by police. Police officers from different regions of the country have been receptive to instruction in effective behavioral principles that enable them to deescalate conflict and improve communication with young people. The fact that juvenile arrests decrease markedly after the dissemination of information about the teen brain and techniques designed to improve communication supports increased participation of child psychiatrists and other mental health clinicians in policing. Additional information about this training is freely available at www.StrategiesforYouth.org.

\section{Acknowledgments}

The authors thank Mark Gillespie, Lieutenant Detective of the Massachusetts Bay Transit Authority Transit Police Department, and the Massachusetts Bay Transit Authority for their support and collaboration in developing this program.

Disclosure: Dr. Bostic has provided expert testimony to Phillips Lytle, LLP. Ms. Thurau is the founder of Strategies for Youth, which has received municipal, state, and private funding to conduct its trainings across the United States. She also has served as a consultant to police misconduct attorneys challenging police treatment of youth. Dr. Drury has received grant or research support from the National Institutes of Health and Tulane University. She has served as a consultant to the Administration on Children, Youth, and Families, and the Southern Poverty Law Center.

\section{REFERENCES}

1. [Accessed December 11, 2013] Strategies for Youth. If not now, when? A survey of juvenile justice training in America's police academies. 2013. Available at: www.strategiesforyouth.org

2. Lopez, CE. [Accessed December 11, 2013] Disorderly (mis)conduct: the problem with "contempt of cop" arrests. Issue Brief. American Constitutional Law Society. 2010. Available at: http:// www.acslaw.org/sites/default/files/Lopez_Contempt_of_Cop.pdf 
3. Shufelt, JJ.; Cocozza, JJ. [Accessed December 11, 2013] Youth with mental health disorders in the juvenile justice system: results from a multi-state prevalence study. Programs and Briefs. National Center for Mental Health and Juvenile Justice. 2006. Accessed: http://www.ncmhjj.com/pdfs/ publications/PrevalenceRPB.pdf

4. Skowyra KR, Cocozza JJ. Blueprint for Change: A Comprehensive Model for the Identification and Treatment of Youth with Mental Health Needs in Contact with the Juvenile Justice System. Delmar, NY National Center for Mental Health, supported by Juvenile Justice and Office of Juvenile Justice and Delinquency Program. 2007

5. Substance Abuse and Mental Health Services Administration. [Accessed December 11, 2013] Building resilience in children and youth dealing with trauma. Available at: www.samhsa.gov/ children/trauma_resilience.asp 


\section{TABLE 1}

\section{Impacts of Police Training At Sites Provided}

\begin{tabular}{|c|c|c|c|c|}
\hline Community & Training Initiated & Officers Trained, $\mathbf{n}$ & & Findings \\
\hline MBTA & 2004 & 190 & 1999-2009 & $\begin{array}{l}\text { juvenile arrests decreased } \\
85 \%\end{array}$ \\
\hline Cambridge, MA, police & 2004 & 250 & 2006-2012 & $\begin{array}{l}\text { juvenile arrests decreased } \\
71 \%\end{array}$ \\
\hline Everett, MA, police & 2007 & 100 & $2007-2010$ & $\begin{array}{l}\text { juvenile arrests decreased } \\
52 \%\end{array}$ \\
\hline Nantucket, MA, police & 2009-2013 & $\begin{array}{c}40 \text { officers, } 90 \\
\text { community safety } \\
\text { officers }\end{array}$ & 2009-2012 & $\begin{array}{l}\text { juvenile arrests decreased } \\
30 \% \text { and change in police } \\
\text { staff to address adolescents }\end{array}$ \\
\hline Salinas, CA, police & 2010 & 30 & no data & $\begin{array}{l}\text { county probation department } \\
\text { leadership adopted approach }\end{array}$ \\
\hline $\begin{array}{l}\text { San Diego, CA, unified school } \\
\text { district }\end{array}$ & 2011 & $\begin{array}{l}55 \text { SROs from various } \\
\text { districts }\end{array}$ & no data & $\begin{array}{l}\text { approach endorsed by } \\
\text { California School Resource } \\
\text { Officers Association }\end{array}$ \\
\hline Ohio, DMC, and training & 2011 & $\begin{array}{l}90 \text { SROs and principals } \\
\text { from various districts }\end{array}$ & no data & $\begin{array}{l}\text { almost } 100 \% \text { reported better } \\
\text { understanding of adolescent } \\
\text { brain's effects on behavior } \\
\text { and alternative policing } \\
\text { approaches }\end{array}$ \\
\hline MBTA training academy & $2010-2012$ & 220 recruits & no data & $\begin{array}{l}\text { persuaded state's law } \\
\text { enforcement agency to make } \\
\text { Strategies for Youth training } \\
\text { required for all future } \\
\text { recruits }\end{array}$ \\
\hline Indianapolis, IN & 2013 & 80 & data being collected & $\begin{array}{l}\text { using alternatives to arrest, } \\
\text { including mental health and } \\
\text { youth serving community- } \\
\text { based organizations }\end{array}$ \\
\hline Charlotte-Mecklenburg, NC, police & 2012 & 65 SROs & $2012-2013$ & $\begin{array}{l}30 \% \text { decrease in school- } \\
\text { based arrests despite } 24 \% \\
\text { increase in calls for service }\end{array}$ \\
\hline Seattle, WA, police & 2103 & 22 & no data & $\begin{array}{l}>98 \% \text { of officers reported } \\
\text { better understanding of } \\
\text { adolescent brain's effects on } \\
\text { behavior and alternative } \\
\text { policing approaches; officers } \\
\text { renamed a trouble spot } \\
\text { "Amygdala Park" }\end{array}$ \\
\hline
\end{tabular}

Note: $\mathrm{DMC}=$ disproportionate minority contact; MBTA = Massachusetts Bay Transit Authority; SROs = school resource officers. 